\title{
An unusual case of rapid radiological progression of bullous emphysema secondary to severe $\alpha 1$-antitrypsin deficiency
}

\author{
Joyce Ruo Yi Chew, ${ }^{1}$ Kay Roy, ${ }^{1}$ Judith Babar, ${ }^{2}$ Ravi Mahadeva ${ }^{1}$
}

${ }^{1}$ Department of Respiratory Medicine, Addenbrooke's Hospital, Cambridge, UK ${ }^{2}$ Department of Radiology, Addenbrooke's Hospital, Cambridge, UK

Correspondence to Dr Joyce Ruo Yi Chew, jcruoyi@gmail.com

Accepted 19 April 2015 Babar J, et al. BMJ Case Rep Published online: [please include Day Month Year] doi:10.1136/bcr-2015209346

\section{DESCRIPTION}

A 68-year-old ex-smoker with known emphysema secondary to severe $\alpha 1$-antitrypsin deficiency (A1ATD) PiZZ phenotype presented with an abrupt onset of worsening breathlessness. His emphysema had shown only mild progression over the years with a forced expiratory volume in $1 \mathrm{~s}$ of $1.36 \mathrm{~L}$ (38.2\% predicted) in 2007 compared with $1.23 \mathrm{~L}(37.2 \%$ predicted) in 2012, and KCO of 0.73 (54.1\% predicted) in 2007 vs $0.61(46.7 \%$ predicted) in 2012 . His condition had rarely been exacerbated and he was able to function independently until the episode. CT of the chest on admission demonstrated the known pan-acinar emphysema and no evidence of a pulmonary embolism. Strikingly, however, there was increased hyperexpansion and bullous changes primarily affecting the right upper lobe (figure 1). He was treated conservatively and discharged, but was readmitted 8 weeks later with worsening breathlessness and chest pain. Repeat CT demonstrated further rapid progression of the pan-acinar emphysema and a new, massive bulla in the left lower lobe measuring at $11 \times 9 \times 11 \mathrm{~cm}$ (figures 2 and 3 ). His respiratory failure deteriorated and he did not survive mechanical ventilation.

This is an unusual case where, following a decade of stable symptoms, there was rapid and profound disease progression within weeks without identifiable triggers. CT has demonstrated dramatic radiological progression of pan-acinar emphysema and rapid bullous formation. Severe A1ATD is associated with a variable

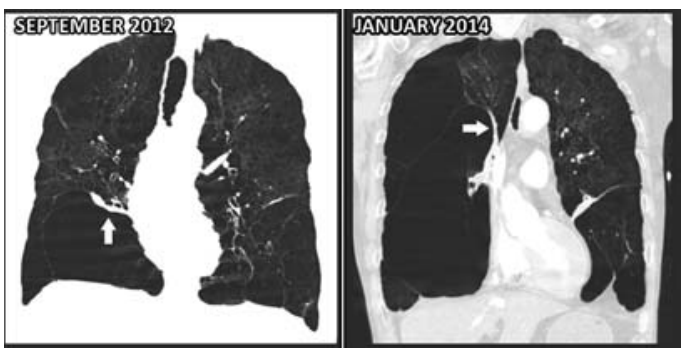

Figure 1 Minimal intensity projection coronal reformat. This post-processing technique highlights the emphysematous bullous regions and demonstrating the increased hyperexpansion and bullous changes primarily affecting the anterior aspect of the right upper lobe with chronic middle lobe collapse (white arrows) over a 16-month interval.

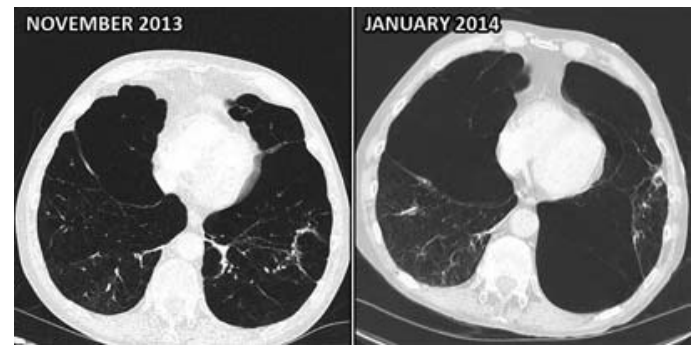

Figure 2 Unenhanced axial high-resolution CT. Interval development of an $11 \times 9 \times 11 \mathrm{~cm}$ bulla in the left lower lobe over a 2-month interval. Background lung parenchyma demonstrating centrilobular and pan-acinar emphysema.

disease progression. Its complex pathophysiology involves enhanced inflammation, gene-environment interactions and forces exerted at a cellular level by the intrinsic biomechanical properties of the lung connective tissue. ${ }^{1}$ This is reflected in the considerable variation in age of onset and severity of chronic obstructive pulmonary disease in patients with A1ATD. ${ }^{2}{ }^{3}$ Hence early identification of the clinical subtypes of disease at greatest risk of a rapidly progressive illness is vital to personalise the surveillance and treatment of each individual patient.

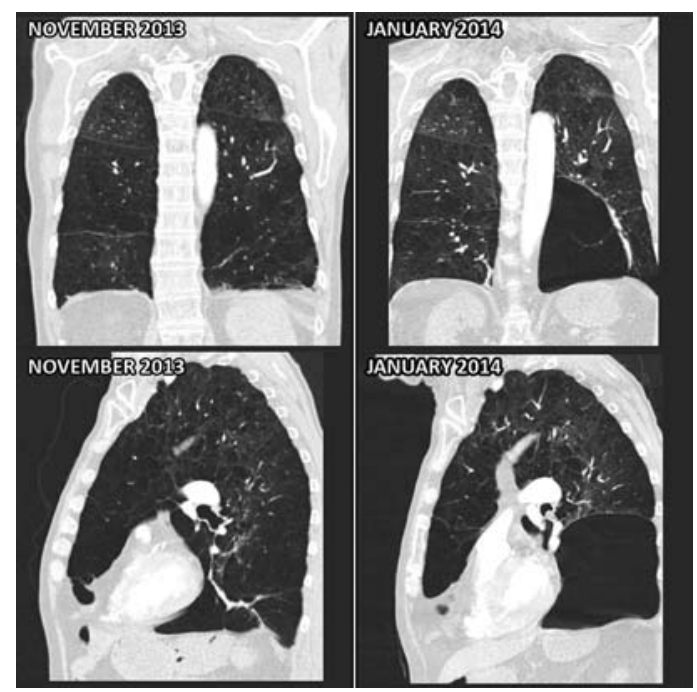

Figure 3 Unenhanced coronal and sagittal reformats demonstrating the development of a multiseptated bulla in the left lower lobe with adjacent compressive atelectasis over a 2-month interval. 


\section{Learning points}

- Severe $\alpha 1$-antitrypsin deficiency (A1ATD) can be associated with sudden and profound decline even in those who have been stable for many years.

- A1ATD is largely underdiagnosed and is associated with premature onset of and rapidly progressive bullous emphysema. Further studies are required to identify potential triggers to this process.

- Future research looks towards epigenetic and biomarker longitudinal studies (as well as more advanced CT scoring) to predict an individual's risk of developing rapidly progressive disease.
Contributors JRYC and KR performed the literature review, drafted the manuscript and were both involved in the patient's care. JB edited the images. RM edited the manuscript and was involved in the patient's care.

Competing interests None declared.

Patient consent Obtained.

Provenance and peer review Not commissioned; externally peer reviewed.

\section{REFERENCES}

1 Kononov S, Brewer K, Sakai $\mathrm{H}$, et al. Roles of mechanical forces and collagen failure in the development of elastase-induced emphysema. Am J Respir Crit Care Med 2001;164(10 Pt 1):1920-6.

2 Alam S, Li Z, Atkinson C, et al. Z $\alpha 1$-antitrypsin confers a proinflammatory phenotype that contributes to chronic obstructive pulmonary disease. Am J Respir Crit Care Med 2014;189:909-31.

3 Stoller JK, Aboussouan LS. $\alpha 1$-Antitrypsin deficiency. Lancet 2005;365:2225-36.

Copyright 2015 BMJ Publishing Group. All rights reserved. For permission to reuse any of this content visit http://group.bmj.com/group/rights-licensing/permissions.

BMJ Case Report Fellows may re-use this article for personal use and teaching without any further permission.

Become a Fellow of BMJ Case Reports today and you can:

- Submit as many cases as you like

- Enjoy fast sympathetic peer review and rapid publication of accepted articles

- Access all the published articles

- Re-use any of the published material for personal use and teaching without further permission

For information on Institutional Fellowships contact consortiasales@bmjgroup.com

Visit casereports.bmj.com for more articles like this and to become a Fellow 